\title{
A Tubular Structural Analogue of Helicene
}

\section{Key words}

helical structures

Friedländer condensation<smiles>O=C1CCC2CCC1Cc1cc3ccccc3nc12</smiles><smiles>Nc1cncnc1C=O</smiles>

$t$-BuOK<smiles>c1ccc2nc3c(cc2c1)CC1CC3Cc2cc3ncncc3nc21</smiles>

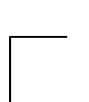<smiles>c1ccc2nc3c(cc2c1)CCCC3</smiles><smiles>Cc1cc2nc3c(cc2nc1C)CC1Cc2nc4cncnc4cc2CC3C1</smiles><smiles>CC(C)(O)O[Na]</smiles><smiles>Nc1cc2c(nc1C=O)C1Cc3cc4ccccc4nc3C(C2)C1</smiles>

$\mathrm{HCl}$

MW<smiles>CC1c2cc3ccccc3nc2C2Cc3cc4nc5c(cc4nc3C1C2)CC1CCC5c2cc(N)c(C=O)nc21</smiles>

$3,87 \%$ yield

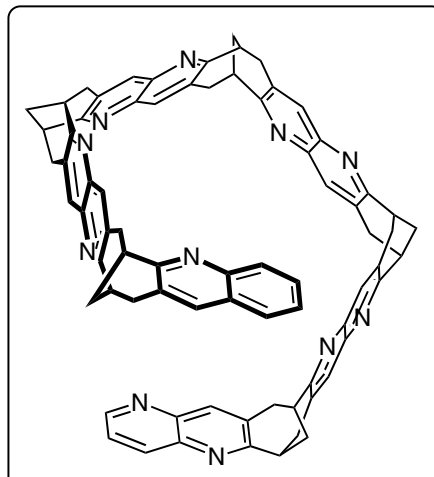

helical structure 1, 76\% yield

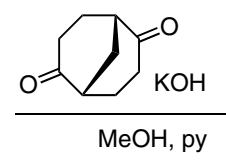

$\mathrm{MeOH}$, py
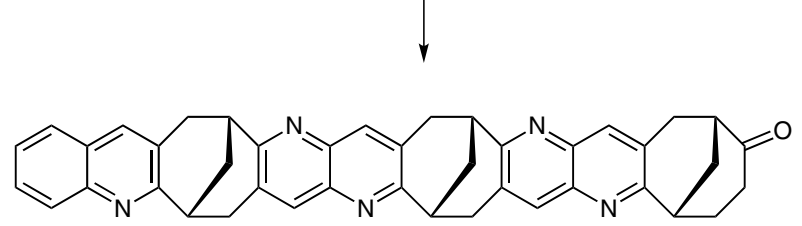

4, $98 \%$ yield

py

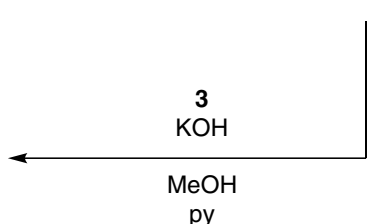

Significance: Helical molecular systems, both natural and unnatural, continue to capture the interests of chemists. Using an enantiomerically pure bicyclic moiety to appropriately place kinks into the system, Wärnmark and co-workers report the synthesis of helical structure $\mathbf{1}$, an orthogonal topological analogue of helicene.
Comment: The synthesis of $\mathbf{1}$ is accomplished by repeated employment of a two-step set of reactions consisting of (1) ring-opening hydrolysis in acid and (2) Friedländer condensation with a chiral bicyclic ketone. By this strategy, monomer $\mathbf{2}$ is converted into ring-opened trimer $\mathbf{3}$, which is converted into trimeric ketone $\mathbf{4}$. Condensation of $\mathbf{4}$ and $\mathbf{3}$ affords the helical target $\mathbf{1}$. 